\title{
LIRAGLUTIDE AND INSULIN DETEMIR IN COMBINATION - A NEW THERAPEUTIC OPTION IN PATIENTS WITH TYPE 2 DIABETES: A CASE REPORT
}

\author{
Milena Velojić-Golubović1,2
}

\begin{abstract}
A recently avaliable new class of type 2 diabetes drugs - glucagon-like peptide- 1 receptor agonists (GLP-1 RA) - has opened new possibilities in diabetes treatment. The most recent guidelines for type 2 diabetes management have clearly positioned this therapeutic option to be used very early in the course of diabetes (after the failure of metformin), but also as an efficient addition to insulin therapy.

We are presenting the case of a type 2 diabetes patient, who did not achieve glycaemic targets despite multiple changes in therapeutic approach. Intensification of diabetes therapy caused in this patient significant weight gain and a higher risk for hypoglycaemic events. At the baseline of our follow up, the therapy with biphasic insulin aspart was switched to basal insulin analogue insulin detemir, in combination with liraglutide (GLP-1 RA) added to metformin. In the first five months of follow-up, the patient achieved significant reduction of $\mathrm{HbA} 1 \mathrm{c}(9.8 \%$ to $6.0 \%)$, average daily glycaemia ( $12.05 \mathrm{mmol} / \mathrm{l}$ to $7.1 \mathrm{mmol} / \mathrm{l}$ ) and frequency of hypoglycaemic events. This combination also caused a significant weight loss $(100 \mathrm{~kg}$ to $90 \mathrm{~kg})$ and reduction in waist circumference $(120 \mathrm{~cm}$ to $116 \mathrm{~cm}$ ), with additional lowering and stabilization of blood pressure. The values reached remained stable throughout the whole year after starting this new drug combination.

From this case report we may conclude that the combination of liraglutide and insulin detemir presents a long-term, very effective, and safe therapeutic option for overweight type 2 diabetic patients.
\end{abstract}

Acta Medica Medianae 2017;56(4):132-137.

Key words: diabetes type 2, obesity, liraglutide, insulin detemir

${ }^{1}$ University of Niš Faculty of Medicine, Niš, Serbia

${ }^{2}$ Clinic of Endocrinology, Clinical Center Niš, Niš, Serbia

Contact: Milena Velojić-Golubović

Sinđelićev trg 28/8. 18000 Niš, Serbia

E-mail: milenavg@yahoo.com

\section{Introduction}

Type 2 diabetes is a chronic, progressive disease, highly associated with obesity and especially abdominal distribution of adipose tissue. A successful treatment of type 2 diabetes means to achieve an effective control of fasting plasma glucose (FPG) and postprandial glucose (PPG), at the same time avoiding additional weight gain and risk of hypoglycaemia. On the other hand, antidiabetic therapy necessary for the glycaemic targets to be achieved is a direct cause of weight gain and hypoglycaemia. Because of these side effects of 132 antidiabetic treatment, a tight glycaemic control is difficult to achieve. Until a few years ago, type 2 diabetes treatment strategy was based exclusively on the use of oral antidiabetic drugs (OAD), the failure of which was followed by the initiation of the basal or premix insulin, usually in combination with metformin. Initiation and intensification of insulin therapy, not in a small number of patients unfortunately, significantly increases the risk of weight gain and hypoglycemia. This results in a failure to achieve glycaemic targets and patient dissatisfaction, which in the end is followed by more chronic complications of diabetes. Recently, a new class of type 2 diabetes drugs has become avaliable - glucagon-like peptide 1 (GLP-1) receptor agonist. Liraglutide (Victoza ${ }^{\circledR}$, Novo Nordisk) is a representative of this group. It is a 97\% homologue with native GLP-1, but with significantly prolonged half-life and bioavailability of 24 hours (1). Liraglutide significantly improves glycaemic control in diabetic patients by stimulating insulin secretion and inhibiting glucagon secretion. A strong advantage of this drug compared to other antidiabetic agents, is that this effect of liraglutide is glucose dependent, which means that it is active 
only when blood sugar levels are high (2). This minimizes the risk of hypoglycaemia and allows a safer use of liraglutide in combination with other drugs. Beyond glycaemic control, liraglutide has also some weight loss results $(3,4)$, leading to significant beneficial metabolic effects and further improvement in glycemic control in people with type 2 diabetes.

\section{Case}

\section{Medical history}

In May 2014, a female patient aged 68 came to the Clinic of Endocrinology, Clinical Center Niš, for glycaemic control and treatment correction if required. She was diagnosed with type 2 diabetes in 2003, and since then was on recommended dietary and lifestyle regimen, although she was never able to adhere strictly to it. Initially, she was treated for seven years with oral antidiabetic agents (metformin 2000 mg/day and glimepiride 6 $\mathrm{mg} /$ day). Because of a poor glycaemic control, her treatment was intensified with NPH insulin in a single evening dose, with discontinuation of glimepiride. Six months later, due to poor glycemic control and hypoglycemia tendency, NPH insulin was switched to basal long-acting insulin analogue, insulin glargine (Lantus, Sanofi Aventis). Despite the titration of insulin glargine, after two years, glycaemic control was still poor (HbA1c >10\%), and it was decided that therapy should be intensified. Basal insulin was replaced with biphasic insulin aspart 30 (BIAsp 30) (NovoMix30 ${ }^{\circledR}$, Novo Nordisk) in two daily doses $-14+0+14$ U. Since glycaemic goals were not achieved, the doses of BiAsp 30 were titrated up to $34+0+34 \mathrm{U}$ (68 U/ 24h), which were the doses at the moment of hospital admission. All the time, the patient used metformin $2000 \mathrm{mg} /$ day.

During insulin treatment, her body weight increased by about $20 \mathrm{~kg}$. Occasionally, there were hypoglycaemic events, although they were significantly less frequent since she was switched to therapy with insulin analogues. Her treshold for hypoglycaemia was $5.0 \mathrm{mmol} / \mathrm{l}$, because at these values she felt low blood sugar symptoms. Because of a strong fear of hypoglycemic events, she ate more then she was recommended. She denied nocturnal hypoglycemia. Her daily blood glucose values ranged from $8.0 \mathrm{mmol}$ to $16.0 \mathrm{mmol} / \mathrm{l}$. Previously, the diagnosis of diabetic polyneuropathy was made. Since 2005, she was treated for arterial hypertension with amlodipine $1 \times 5 \mathrm{mg}$, nebivolol $1 \times 5 \mathrm{mg}$ and cilazapril plus hydrochlorothiazide 2x1 tablet. With this triple therapy, her blood pressure was measured up to $150 / 90 \mathrm{mmHg}$. Occasionally, the patient was using fenofibrate for her elevated triglyceride levels. There was no familiy history of diabetes, and her brother died of lung cancer. She was smoking 10 cigarettes a day for 25 years.

\section{Status at hospital admission}

During physical examination, except obesity, all the other parameters were normal. Her anthropometric measures were recorded: body weight $100 \mathrm{~kg}$, height - $163 \mathrm{~cm}$, body mass index (BMI) - $38.5 \mathrm{~kg} / \mathrm{m}^{2}$, waist circumference $-120 \mathrm{~cm}$, hip circumference - $122 \mathrm{~cm}$, and waist/hip ratio (W/ H) -0.98 . Her blood pressure was $135 / 90 \mathrm{mmHg}$ and heart rate (HR) 80/min. Glycaemic parameters showed a poor glycaemic control. HbA1c was

Table 1. Anthropometric measurements, glycaemic parameteres and blood tests during 1 year of follow up

\begin{tabular}{|c|c|c|c|}
\hline & Baseline & After 5 months & After 12 months \\
\hline Body weight $(\mathrm{kg})$ & 100 & 90 & 93 \\
\hline BMI $\left(\mathrm{kg} / \mathrm{m}^{2}\right)$ & 38,5 & 34,6 & 35,7 \\
\hline Waist circumference $(\mathrm{cm})$ & 120 & 116 & 114 \\
\hline Hip circumference $(\mathrm{cm})$ & 122 & 120 & 120 \\
\hline $\mathrm{W} / \mathrm{H}$ ratio & 0,98 & 0,96 & 0,95 \\
\hline HbA1c (\%) & 9,8 & 6,0 & 6,8 \\
\hline FPG $(\mathrm{mmol} / \mathrm{l})$ & 14,0 & 5,8 & 6,8 \\
\hline Glycaemia after breakfast $(\mathrm{mmol} / \mathrm{l})$ & 10,6 & 7,1 & 7,3 \\
\hline Glycaemia before lunch (mmol/l) & 15,2 & 6,6 & 7,4 \\
\hline Glycaemia after lunch (mmol/l) & 15,0 & 8,9 & 9,6 \\
\hline Glycaemia before dinner ( $\mathrm{mmol} / \mathrm{l})$ & 13,0 & 6,7 & 7,2 \\
\hline Glycaemia after dinner (mmol/l) & 9,3 & 8,2 & 9,4 \\
\hline Glycaemia before bed (mmol/l) & 8,9 & 7,4 & 7,6 \\
\hline Glycaemia at $03 \mathrm{AM}(\mathrm{mmol} / \mathrm{l})$ & 10,4 & 6,3 & 5,2 \\
\hline Average daily glycaemia (mmol/l) & 12,05 & 7,1 & 7,6 \\
\hline Total cholesterol $(\mathrm{mmol} / \mathrm{l})$ & 6,7 & 6,33 & 5,7 \\
\hline $\mathrm{LDL}(\mathrm{mmol} / \mathrm{I})$ & $>3,4$ & 3,9 & 3,2 \\
\hline $\mathrm{HDL}(\mathrm{mmol} / \mathrm{I})$ & 0,97 & 0,98 & 0,98 \\
\hline Triglycerids (mmol/l) & 5,46 & 3,55 & 3,4 \\
\hline Blood pressure $(\mathrm{mmHg})$ & $135 / 90$ & $110 / 70$ & $120 / 70$ \\
\hline Hearth rate (beats/ minute) & 80 & 76 & 76 \\
\hline
\end{tabular}

MI - body mass index, W/H - waist-hip, FPG - fasting plasma glucose 
9.8\%. In her daily glucose profile, the values ranged from $8.9 \mathrm{mmol} / \mathrm{l}$ in the morning, to 15.2 after lunch, with the average of $12.05 \mathrm{mmol} / \mathrm{l}$. As for blood biochemistry, elevated lipid levels were noted: total cholesterol $6.7 \mathrm{mmol} / \mathrm{l}, \mathrm{HDL} 0.97 \mathrm{mmol} /$ I, LDL >3.4 mmol/l, triglycerids (Tgc) $5.46 \mathrm{mmol} / \mathrm{l}$. Microalbuminuria was present in the urine. The degree of glomerular filtration was determined. We performed fundoscopy and established the presence of an incipient cataract. Anthropometric measurements, glycaemic parameteres and blood tests at the moment of admission to the hospital are presented in Table 1.

We decided that a change of antidiabetic treatment is necessary beacuse of poor glycaemic control, which was the consequence of poorly chosen, right therapy for this specific patient in time. We decided to switch from biphasic insulin analogue to the combination of metformin, basal insulin and liraglutide. As basal insulin, we initiated insulin detemir (Levemir ${ }^{\circledR}$ Novo Nordisk), the dose of which was titrated up to $54 \mathrm{U} / 24 \mathrm{~h}$ in a single evening dose. The therapy with liraglutide was initiated at a dose of $0.6 \mathrm{mg} /$ day during the first week, and after that the dose was increased to 1.2 $\mathrm{mg} /$ day. The patient denied any gastrointestinal symptoms that could be linked to the therapy. This therapy produced significant improvements in glycaemic control already during the hospital stay that lasted for two weeks. On hospital discharge, her glucose profile showed the values of FPG 6.8 $\mathrm{mmol} / \mathrm{l}$ and PPG $10.9 \mathrm{mmol} / \mathrm{l}$, with the average of $8.13 \mathrm{mmol} / \mathrm{l}$. We also recommanded the use of statins and fibrate, as well as strict adherence to the dietary regimen.

\section{Control after 5 months}

Patient came to regular check-ups, and stated that she felt very well since the new therapy was introduced, and doses remained unchanged for the whole time. During this period, the patient reported only mild nausea occasionally, which diminished with the use of ranitidine. She denied any hypoglycaemia. In her self-control diary, her blood glucose ranged from 6.2 to $9.5 \mathrm{mmol} / \mathrm{l}$. On her own initiative she checked her HbA1c after only a month and a half of new therapy, and it dropped to $8.1 \%$. She noticed that her appetite was reduced, and she felt her blood pressure was lower.

On physical examination, a weight loss was obvious: body weight - $90 \mathrm{~kg}$, waist circumference - $116 \mathrm{~cm}$, hip circumference - $120 \mathrm{~cm}$, BMI $34.6 \mathrm{~kg} / \mathrm{m}^{2}, \mathrm{~W} / \mathrm{H}$ ratio 0.96 . Her blood pressure was $110 / 70 \mathrm{mmHg}$ and $\mathrm{HR} 76 / \mathrm{min}$. On the day of the control, her glucose ranged from FPG that was $5.8 \mathrm{mmol} / \mathrm{l}$, and PPG after lunch $8.9 \mathrm{mmol} / \mathrm{l}$, with the average of $7.1 \mathrm{mmol} / \mathrm{l}$. HbA1c was $6.0 \%$. On blood testing, her total cholesterol was 6,33 $\mathrm{mmol} / \mathrm{l}$, LDL $3.90 \mathrm{mmol} / \mathrm{l}, \mathrm{HDL} 0.84 \mathrm{mmol} / \mathrm{l}$, and Tgc $3.55 \mathrm{mmol} / \mathrm{I}$. All the measurements and relevant labaratory tests done after 5 months are presented in Table 1 . Other biochemical parameters were within the reference range. We recommended that the patient should continue with unchanged doses of the prescribed therapy.

\section{Control after 12 months}

During the whole year after new therapy was initiated, the patient regularly took all the recommended drugs in the same doses as initially. She claimed that she felt very well, without any side effects or hypoglycaemia. This caused a more flexibile dietary regimen, and a looser adherence to recommendations. Despite this fact, in her selfcontrol diary, blood glucose values ranged from 4.3 to $10.5 \mathrm{mmol} / \mathrm{l}$. Anthropometric measurements were stable since the last check-up: body weight - $93 \mathrm{~kg}$, waist - $114 \mathrm{~cm}$, hip $-120 \mathrm{~cm}$, BMI $35.7 \mathrm{~kg} / \mathrm{m}^{2}, \mathrm{~W} / \mathrm{H}$ ratio 0.95 . Her blood pressure was 120/ $70 \mathrm{mmHg}$, and HR 76/min. Glycaemic control was also stable, with FPG 8 $\mathrm{mmol} / \mathrm{l}$ on the day of the control and $\mathrm{HbA} 1 \mathrm{c} 6.8 \%$. Blood testing showed total holesterol of 5.7 $\mathrm{mmol} / \mathrm{l}$, LDL $3.2 \mathrm{mmol} / \mathrm{l}$, HDL $0.98 \mathrm{mmol} / \mathrm{l}$, Tgc $3.4 \mathrm{mmol} / \mathrm{l}$. These data are presented in Table 1 , and all the other measured values were in the reference range. The patient was advised to continue without any changes to the recommended treatment.

\section{Discussion}

Over time, due to disease progression, in at least $50 \%$ of type 2 diabetes patients, insulin therapy becomes necessary (5). A strict control of hyperglycaemia with insulin often leads to weight gain, but more importantly increases the risk of hypoglycaemia. These side effects of insulin therapy usually discourage patients in their attempt to reach the glycaemic target. This leads to nonadherence to therapy, and they even more often do away with the recommended dietary regimen. In this situation of poor glycaemic control, a doctor has to intensify the therapy. However, since the problem was not the efficacy of therapy but its side effects, the goals could not be achieved. Such an outcome makes both the patient and the physician frustrated, and altogether results in adopting less demanding targets in glycemic regulation, with the consequences of such a compromise.

The patient presented here confirms these claims. At the time of hospital admission, the next step according to diabetes therapy guidelines would be further stepping-up of insulin treatment (6). The major obstacles to this option would be significant weight gain of the patient and hypoglycaemia, followed by patient's fear. This would draw in the patient into a viciuos circle of more insulin, more hypoglycamia, more weight gain, less motivation, more eating, worse glycaemic control. Knowing all these facts, we decided to try to stop that vicious circle and adjust the therapy to our patient's needs. Having in mind the mecha- 
nisms of action of antidiabetic drugs and most recent guidelines for diabetes treatment published by the ADA/EASD (American Diabetes Association/European Association for the Study of Diabetes) (6) and AACE (American Association of Clinical Endocrinologists) (7), we decided to take a step back in the treatment algorithm to basal insulin combined with liraglutide. Insulin detemir was chosen as basal insulin, predominantly because of its confirmed weight-neutral effect (8) compared to all other insulins. The patient would also benefit from detemir, because of its unique mode of action (causing low glucose variability and low risk of hypoglycaemia) $(9,10)$. The initiation of liraglutide was motivated by four major advantages of the drug: its high efficacy in glycaemic control, very low risk of hypoglycaemia, weight loss effects and very important glucose-dependent mode of action which allows an efficiant lowering of postprandial glucose (11-17). All four factors were very important for our patient, who managed to overcome the obstacles mentioned and succeded in achieving glycaemic targets. This was evidenced by a highly significant improvement in glycaemic control, with $\mathrm{HbA} 1 \mathrm{c}$ dropping by $3.0 \%$ until the end of the follow-up period.

Basal insulin and GLP-1 agents may be complementary treatment options for the patients with type 2 diabetes, since insulin corrects the basic pathophysiological defect, and GLP-1 improves insulin secretion and reduces glucagon secretion (18-21). On the other hand, liraglutide has also a role in increasing satiety, decreasing food intake and slowing down gastric emptying, which all lead to a reduction in caloric intake (22). Several studies clearly showed that treatment with liraglutide resulted in weight loss, specifically in a greater reduction of adipose tissue compared to lean mass. In fact, the use of this drug reduced more visceral than subcutaneous fat tissue (4, 21 ). This is a very important fact if one bears in mind the importance of obesity as well as its implications, primarily on increased morbidity and mortality from cardiovascular diseases.

The combination of liraglutide with insulin seems to be an attractive therapeutic option for our patient, since a significant improvement in glycaemic control was followed by considerable reduction in body weight and reduced risk of hypoglycaemia. This therapeutic approach significantly reduced the effect of insulin on weight gain and led to statistically significant weight loss of $10 \%$ in the first five months of therapy (a drop from 100 to $90 \mathrm{~kg}$ ), with a greater reduction in abdominal fat (waist circumference $120 \mathrm{~cm}$ vs. $114 \mathrm{~cm}$ ). There was no additional education of the patient about the diet and physucal activity that could have influenced weight reduction. Although there was no further weight reduction in the follow-up period, the achieved weight stability was very important. The combination of liraglutide with insulin caused also a significant reduction in the total daily dose of insulin by $20 \%$ ( 68 vs. 54 U/24h). The experience of other authors show that one should expect reduction of insulin dose by $15 \%$ to $63 \%$, when combined with a GLP-1 receptor agonist (20). We believe that there are four reasons why this therapeutic combination helped weight reduction: direct effect of liraglutide on weight loss, direct effect of detemir on weight, prevention of weight gain by reducing the dose of insulin and less hypoglycaemia causing less defensive eating.

Although most studies recommend the dose of liraglutide of $1.8 \mathrm{mg} /$ day (11), we have shown that a dose of $1.2 \mathrm{mg} /$ day can also achieve the desired results, with a minimal incidence of adverse events, primarily those in gastrointestinal tract. Gastric symptoms can be a limiting factor for the use of a GLP-1 agonist, and concomitant use of insulin in this case probably reduced the need for a full dose of liraglutide. This further justifies the use of this combination.

We would like to point out the effect of liraglutide on blood pressure. The introduction of liraglutide in our patient caused a reduction of blood pressure (135/90 vs.110/70 $\mathrm{mmHg}$ ), that remained unchanged during the whole follow-up period. Other authors also pointed out the effect of liraglutide on the reduction of the systolic blood pressure in the first place. They demonstrated a reduction of systolic blood pressure by 2.6-3.3 $\mathrm{mmHg}$ in the first two weeks of therapy, prior to any significant weight loss (23).

In conclusion, we would like to point out that the treatment of type 2 diabetes requires an approach tailored to each individual patient and that GLP-1 agonists opened a new promising area of therapy that is both effective and (even more importantly) safe. Liraglutide is a drug that was initially recommended as second-line therapy (after metformin failure), but the clinical studies conducted in the last few years clearly showed that it was a sound option across all stages of diabetes. The combination of insulin detemir and liraglutide allows long periods of adequate and stable metabolic control of diabetes type 2, without any significant side effects. 


\section{References}

1. Agersø $H$, Jensen LB, Elbrønd B, Rolan $P$, Zdravković M. The pharmacokinetics, pharmaco dynamics, safety and tolerability of NN2211, a new long-acting GLP-1 derivate, in healthy men. Diabetologia 2002; 45(2): 195-202. [CrossRef] [PubMed]

2. Nauck MA, Kleine N, Orskov C, Holst JJ, Willms B, Creutzfeldt W. Normalization of fasting hyper glycaemia by exogenous glucagon-like peptide 1 (736 amide) in type 2 (non-insulin-dependant) diabetic patient. Diabetologia 1993; 36(8): 741-4. [CrossRef] [PubMed]

3. Niswender $\mathrm{K}$, Pi-Sunyer $\mathrm{X}$, Buse J, Jensen $\mathrm{KH}$, Toft $A D$, Russell-Jones $D$, et al. Weight change with liraglutide and comparator therapies: an analysis of seven phase 3 trials from the liraglutide diabetes development programme. Diabetes Obes Metab 2013; 15(1): 42-54. [CrossRef][PubMed]

4. Vilsbøll $T$, Christensen M, Junker AE, Knop FK, Gluud LL. Effects of glucagon-like peptide-1 receptor agonists on weight loss: systematic review and meta-analyses of randomised controlled trials. BM] 2012; 344: d7771. [CrossRef][PubMed]

5. Lane W, Weinrib S, Rappaport J, Hale C.The effect of addition of liraglutide to high-dose intensive insulin therapy: a randomized prospective trial. Diabetes Obes Metab 2014; 16(9): 827-32. [CrossRef] [PubMed]

6. Inzucchi SE, Bergenstal RM, Buse JB, Diamant M, Ferrannini $E$, Nuck $M$, et al. Management of hyperglycemia in type 2 diabetes, 2015: a patientcentered approach: Update to a position statement of the American Diabetes Association and the European Association for the Study of Diabetes. Diabetes Care 2015; 38: 140-9. [CrossRef] [PubMed]

7. Garber AJ, Abrahamson MJ, Barzilay JI, Blonde L, Bloomgarden ZT, Bush MA, et al. AACE Comprehensive diabetes management algorithm 2013. Endocr Pract 2013; 19(2): 327-36. [CrossRef] [PubMed]

8. Niswender $\mathrm{K}$, Piletic M, Andersen $\mathrm{H}$, Conradsen Hiort L, Hollander P. Weight change upon oncedaily initiation of insulin detemir with or without dietary intervention in overweight or obese insulinna" Ive individuals with type 2 diabetes: results from the DIET trial. Diabetes Obes Metab 2014; 16(2): 186-92. [CrossRef][PubMed]

9. Klein O, Lynge J, Endahl L, Damholt B, Nosek L, Heise T. Albumin-bound basal insulin analogues (insulin detemir and NN344): comparable timeaction profiles but less variability than insulin glargine in type 2 diabetes. Diabetes Obes Metab 2007; 9(3): 290-9. [CrossRef][PubMed]

10. Heise T, Nosek L, Rønn BB, Endahl L, Heinemann L, Kapitza C, et al. Lower within-subject variability of insulin detemir in comparison to $\mathrm{NPH}$ insulin and insulin glargine in people with type 1 diabetes. Diabetes 2004; 53(6): 1614-20. [CrossRef] [PubMed]

11. Zinman B, Schmidt WE, Moses A, Lund N, Gough S. Achieving a clinically relevant composite outcome of an $\mathrm{HbA} 1 \mathrm{c}$ of $<7 \%$ without weight gain or hypogly caemia in type 2 diabetes: a meta-analysis of the liraglutide clinical trial programme. Diabetes Obes Metab 2012; 14(1): 77-82. [CrossRef] [PubMed]

12. Chitnis AS, Ganz ML, Benjamin N, Langer J, Hammer M. Clinical effectiveness of liraglutide across body mass index in patients with type 2 diabetes in the United States: a retrospective cohort study. Adv Ther 2014; 31(9): 986-99. [CrossRef][PubMed]

13. Chiefari E, Capula C, Vero A, Oliverio R, Puccio L, Liguori $\mathrm{R}$, et al. Add-on treatment with liraglutide improves glycemic control in patients with type 2 diabetes on metformin therapy. Diabetes Technol Ther 2015; 17(7): 468-74. [CrossRef][PubMed]

14. Fadini GP, Simioni N, Frison V, Dal Pos M, Bettio M, Rocchini $P$, et al. Independent glucose and weightreducing effects of liraglutide in a real-world population of type 2 diabetic outpatients. Acta Diabetol 2013; 50(6): 943-9. [CrossRef][PubMed]

15. Flint A, Kapitza C, Hindsberger C, Zdravković M. The once-daily human glucagon-like peptide-1 (GLP-1) analog liraglutide improves postprandial glucose levels in type 2 diabetes patients. Adv Ther 2011; 28(3): 213-26. [CrossRef][PubMed]

16. Peterson GE, Pollom RD. Liraglutide in type 2 diabetes: from design to clinical practice. Int J Clin Pract 2010; 64 (167): 35-43.

17. De Wit HM, Vervoort GM, Jansen HJ, de Grauw WJ, de Galan BE, Tack CJ. Liraglutide reverses pronounced insulin-associated weight gain, improves glycaemic control and decreases insulin dose in patients with type 2 diabetes: a 26 week, randomized clinical trial (ELEGANT). Diabetologia 2014; 57(9): 1812-9. [CrossRef][PubMed]

18. Vora J. Combining incretin-based therapies with insulin: realizing the potential in type 2 diabetes. Diabetes Care 2013; 36(2): 226-32. [CrossRef] [PubMed]

19. Lipowsky C, Sze L, Krull I, Brändle M. Liraglutide as add-on therapy to insulin in type 2 diabetes mellitus: a retrospective, observational study from a daily clinical practice setting in Switzerland. Diabetes Ther 2015; 6(1): 41-7. [CrossRef] [PubMed]

20. Kalra S. Insulin and glucagon-like peptide receptor agonist (GLP1 RA) combinations. J Pak Med Assoc 2014; 64(3): 359-61. [PubMed]

21. Li CJ, Li J, Zhang QM, Lv L, Chen R, Lv CF, et al. Efficacy and safety comparison between liraglutide as add-on therapy to insulin and insulin doseincrease in Chinese subjects with poorly controlled type 2 diabetes and abdominal obesity. Cardiovasc Diabetol 2012; 11:142. [CrossRef][PubMed]

22. Flint A, Raben A, Astrup A, Holst JJ. Glucagon-like peptide 1 promotes satiety and suppresses energy intake in humans. J Clin Invest 1998; 101(3): 51520. [CrossRef][PubMed]

23. Fonseca VA, Devries JH, Henry RR, Donsmark M, Thomsen HF, Plutzky J. Reductions in systolic blood pressure with liraglutide in patients with type 2 diabetes: insights from a patient-level pooled analysis of six randomized clinical trials. J Diabetes Complication 2014; 28(3): 399-405. [CrossRef] [PubMed] 


\title{
LIRAGLUTID I INSULIN DETEMIR U KOMBINACIJI - NOVI TERAPIJSKI IZBOR KOD OSOBA SA DIJABETESOM TIP 2: PRIKAZ SLUČAJA
}

\author{
Milena Velojić-Golubović1,2
}

\author{
${ }^{1}$ Univerzitet u Nišu, Medicinski fakultet, Niš, Srbija \\ ${ }^{2}$ Klinika za endokrinologiju, Klinički centar Niš, Niš, Srbija \\ Kontakt: Milena Velojić-Golubović \\ Sinđelićev trg 28/8. 18000 Niš, Srbija \\ E-mail: milenavg@yahoo.com
}

Od skoro dostupna nova klasa lekova u terapiji dijabetesa tipa 2 - agonisti receptora glukagonu sličanog peptida-1 (GLP-1 RA), otvorila je nove mogućnosti u tretmanu ovog oboljenja. Najnoviji preporučeni terapijski algoritmi za lečenje dijabetesa tipa 2 jasno pozicioniraju ovu terapijsku opciju u najranijoj fazi lečenja (nakon neuspeha metformina), ali i kasnije, kao vrlo efektivnu dopunu insulinskoj terapiji.

Prikazali smo osobu koja boluje od dijabetesa tipa 2, i kod koje, uprkos promenama terapijskog pristupa, nije postignuta dobra glikemijska kontrola u dugom periodu trajanja bolesti. Intenziviranje terapije je zapravo samo uslovilo značajan porast telesne težine i rizika od hipoglikemijskih epizoda. Aktuelna terapija bifaznim insulinskim analogom zamenjena je bazalnim insulinskim analogom - insulinom detemir, u kombinaciji sa liraglutidom (GLP-1 RA) i metforminom. U prvih pet meseci primene postignuta je značajna redukacija HbA1c $(9,8 \%-6,0 \%)$, prosečne dnevne glikemije $(12,05$ $\mathrm{mmol} / \mathrm{l}-7,1 \mathrm{mmol} / \mathrm{l})$, kao i učestalosti hipoglikemijskih epizoda. Ova terapijska kombinacija je uslovila i značajan gubitak telesne težine $(100 \mathrm{~kg}-90 \mathrm{~kg})$ i smanjenje obima struka $(120 \mathrm{~cm}-116 \mathrm{~cm})$, uz snižavanje i stabilizaciju vrednosti krvnog pritiska. Postignuti efekti su se održali tokom godinu dana praćenja od uvođenja nove terapije.

Iz ovog prikaza slučaja može se zaključiti da kombinacija liraglutida i insulinA detemira prestavlja visoko efikasnu i bezbednu terapijsku opciju za gojazne osobe sa tipom 2 dijabetesa u dužem vremenskom periodu.

$$
\text { Acta Medica Medianae 2017;56(4):132-137. }
$$

Ključne reči: dijabetes tip 2, gojaznost, liraglutid, insulin detemir 